\title{
Responses to homeostatic signals in ractopamine-treated pigs
}

\author{
BY F. R. DUNSHEA AND R. H. KING \\ Victorian Institute of Animal Science, Werribee 3030, Australia
}

(Received 9 May 1994 - Revised 24 October 1994-Accepted 8 November 1994)

\begin{abstract}
The $\beta$-agonist ractopamine $(\mathrm{RAC})$ promotes protein deposition with little effect on fat deposition in the pig. To assess whether the lack of effect on fat deposition was due to changes in response to homeostatic signals, eight crossbred gilts ( $73 \mathrm{~kg}$ body weight $(\mathrm{BW})$ ) with venous catheters were used to examine plasma metabolite and hormone concentrations before and after intravenous injections of insulin and the $\beta_{2}$-agonist fenoterol during dietary RAC $(0$ or $20 \mathrm{mg} / \mathrm{kg})$ treatment. Pigs received intravenous challenges of insulin $(1 \mu \mathrm{g} / \mathrm{kg} \mathrm{BW})$ on days 3,9 and 23 and fenoterol $(2 \mu \mathrm{g} / \mathrm{kg} \mathrm{BW})$ on days 4,10 and 24 of treatment. RAC was then withdrawn from the diet and insulin and fenoterol challenges were repeated 6 and $7 \mathrm{~d}$ later respectively. Blood samples for the determination of metabolite and hormone concentrations were taken at $-30,-20,-10,-1,2 \cdot 5,5,10,20,30,45,60$ and 120 min relative to the challenges. Dietary RAC decreased basal plasma insulin concentrations but had no effect on plasma glucose or non-esterified fatty acids (NEFA). Hypoglycaemic responses to insulin were not affected by RAC while the anti-lipolytic effects of insulin tended to be augmented. Dietary RAC decreased the lipolytic response to fenoterol, this being evident after $4 \mathrm{~d}$ treatment. Hypoglycaemic response to fenoterol was not changed whereas the hyperinsulinaemic response to fenoterol was attenuated by dietary RAC. Previous treatment with RAC did not influence basal hormone and metabolite concentrations or responses to homeostatic signals during the withdrawal period. While these results suggest little change in glucose metabolism, the de-sensitization of adipose tissue $\beta$-adrenergic receptors is consistent with the observations that dietary RAC has little effect on the rate of fat deposition in the growing pig.
\end{abstract}

$\beta$-Agonist: Non-esterified fatty acids: Glucose: Pig

Previous studies have demonstrated that the $\beta$-agonist ractopamine (RAC) is a stimulator of protein deposition in growing pigs (Mitchell et al. 1990, 1991; Dunshea et al. $1993 a, b, c)$. However, effects on lipid deposition have been more equivocal. While bodyfat content and backfat depths have been consistently decreased by RAC and other $\beta$ agonists, in the few studies where the actual rate of lipid deposition has been measured by slaughter balance the effects are far from consistent. For example, we have failed to observe any decrease in the rate of lipid deposition (i.e. $\mathrm{g} / \mathrm{d}$ ) in pigs fed on a wide range of energy and protein intakes (Dunshea et al. 1993a,b,c). Mitchell et al. (1990) found that RAC decreased lipid deposition in their low-select line (selected for lean growth when fed on diet containing $120 \mathrm{~g}$ crude protein (CP) $/ \mathrm{kg}$ ) of barrows when they were fed on a ration containing $120 \mathrm{~g} \mathrm{CP} / \mathrm{kg}$ but not when fed on a $240 \mathrm{~g} \mathrm{CP} / \mathrm{kg}$ diet. Lipid deposition was not altered by RAC in their high-select (selected for lean growth when fed on a diet containing $240 \mathrm{~g} \mathrm{CP} / \mathrm{kg}$ ) line of pigs irrespective of dietary protein content. RAC decreased lipid deposition in barrows when fed ad lib. but not when fed restrictively (Mitchell et al. 1991). Therefore, it appears that under some circumstances RAC and possibly other $\beta$-agonists can decrease lipid deposition in pigs but that this effect is relatively small and variable in magnitude. The aim of the present experiment was to determine whether responses to homeostatic signals such as $\beta$-adrenergic stimulation or insulin are altered during dietary RAC treatment and thus contribute to the relative lack of effect on fat deposition observed 
during RAC treatment of pigs. The $\beta_{2}$-agonist fenoterol was chosen as the model $\beta$-agonist since porcine adipose tissue contains predominantly $\beta_{2}$-adrenergic receptors (Coutinho et al. 1990).

\section{MATERIALS AND METHODS}

\section{Animals and surgery}

Eight crossbred (Large White $\times$ Landrace) gilts (initial body weight (BW) $73 \mathrm{~kg}$ ) were maintained in individual pens throughout the study. Animals were housed under a $14 \mathrm{~h}$ light $-8 \mathrm{~h}$ dark cycle with lights being turned on at 07.00 hours. Pigs were catheterized at least $7 \mathrm{~d}$ before commencement of the study. Muscle relaxation was induced with an intramuscular injection of azoperone (Stresnil, $40 \mathrm{mg} / \mathrm{ml}$; Boehringer, NSW, Australia) after which anaesthesia was induced and maintained with halothane (Fluothane; ICI, Victoria, Australia). A silastic catheter (Sil-Med Corporation, Taunton, MA, USA; $0.16 \mathrm{~mm}$ i.d., $0.32 \mathrm{~mm}$ o.d.) was inserted $150 \mathrm{~mm}$ into the anterior vena cava via the cephalic vein (Takken \& Williams, 1981). The catheter was exteriorized in the region of the interscapular space on the back of the animals and stored in a cloth pocket glued to the back. After catheterization pigs were given a $4 \mathrm{~d}$ course of broad spectrum antibiotic (Terramycin/LA, oxytetracycline $200 \mathrm{mg} / \mathrm{ml}$; Pfizer, NSW, Australia) and exit wounds were treated with antibiotic powder (Terramycin, oxytetracycline, $20 \mathrm{mg} / \mathrm{g}$; Pfizer). Catheters were flushed daily with physiological saline containing $\mathrm{K}_{2}$ EDTA $(12.5 \mathrm{~g} / 1)$.

\section{Experimental procedures}

For $4 \mathrm{~d}$ before initiation of the dietary treatments pigs were offered $500 \mathrm{~g}$ of a nutrientdense diet (Table 1) every $4 \mathrm{~h}$. Commencing at 08.00 hours on day 1 pigs were offered their ration containing either 0 or $20 \mathrm{mg}$ ractopamine. $\mathrm{HCl} / \mathrm{kg}$ for $24 \mathrm{~d}$. From day 25 until day 30 all pigs were fed on the diet containing $0 \mathrm{mg} \mathrm{RAC} / \mathrm{kg}$. Pigs received an intravenous challenge of insulin (Actrapid MC; Novo Industri, Copenhagen, Denmark; $1 \mu \mathrm{g} / \mathrm{kg} \mathrm{BW}$ ) on days 3,9 and 23 to determine plasma metabolite and hormone responses to insulin. Challenges of the $\beta_{2}$-agonist fenoterol (Sigma Chemical Co., St Louis, MO, USA; $2 \mu \mathrm{g} / \mathrm{kg}$ BW) were administered on days 4,10 and 24 to determine plasma metabolite and hormone responses to $\beta$-adrenergic stimulation. Insulin and fenoterol challenges were again administered on days 30 and 31 (i.e. 6 and $7 \mathrm{~d}$ after withdrawal of RAC) respectively. Blood samples $(8 \mathrm{ml})$ were taken at $-30,-20,-10,-1,2 \cdot 5,5,10,20,30,45,60$ and $120 \mathrm{~min}$ relative to challenges and placed in heparinized tubes $(60 \mathrm{U} / \mathrm{ml})$ on ice. After low-speed centrifugation, plasma was harvested and stored at $-70^{\circ}$ until analysed for glucose, nonesterified fatty acids (NEFA) and insulin.

\section{Plasma analyses}

Plasma glucose was analysed using an enzymic kit assay based on linked glucose oxidase (EC 1.1.3.4)-peroxidase (EC 1.11.1.7) reactions (Sigma Chemical Co.; Cat. no. 510). Plasma NEFA were analysed using an enzymic kit assay based on linked acyl-CoA synthetase $(E C 6.2 .1 .3)$-acyl-CoA oxidase $(E C$ 1.3.3.6)-peroxidase reactions (Boehringer Mannheim, Germany; Cat. no. 1082 914) modified to conduct additional assays by a five-fold dilution of all reagents with $0.025 \mathrm{M}$-potassium phosphate buffer $(\mathrm{pH} 7.8)$. Plasma insulin was analysed using a commercial kit (Amersham, Bucks.) using recombinant human insulin as a standard. Analyses for each metabolite or hormone for each challenge day included plasma samples obtained from four pigs (two from each treatment). All analyses were performed in duplicate with pools included in each assay. Inter- and intraassay coefficients of variation were 2.7 and $1.1 \%, 11.4$ and $2.7 \%$ and 9.0 and $5.3 \%$ for glucose, NEFA and insulin respectively. 
Table 1. Composition of the experimental diet*

\begin{tabular}{lc}
\hline \hline Ingredient & $\mathrm{g} / \mathrm{kg}$ \\
\hline Wheat & $774 \cdot 6$ \\
Soya-bean meal & $116 \cdot 1$ \\
Meat-and-bone meal & $37 \cdot 65$ \\
Blood meal & $30 \cdot 0$ \\
Fat blend & $20 \cdot 0$ \\
Limestone & $8 \cdot 56$ \\
Dicalcium phosphate & $5 \cdot 72$ \\
L-Lysine.HCl & $2 \cdot 5$ \\
DL-Methionine & $0 \cdot 80$ \\
Vitamin and mineral premix $\dagger$ & $2 \cdot 0$ \\
Salt & $2 \cdot 0$ \\
\hline
\end{tabular}

* Diet formulated to contain $183 \mathrm{~g}$ crude protein $/ \mathrm{kg}, 14.5 \mathrm{MJ} \mathrm{DE} / \mathrm{kg}$ and $10.8 \mathrm{~g}$ lysine $/ \mathrm{kg}$.

$\uparrow$ Provided the following nutrients (mg/kg air-dry diet): retinol 6.4, cholecalciferol $0.083, \alpha$-tocopherol 22, menadione $0 \cdot 60$, riboflavin $3 \cdot 3$, nicotinic acid $16 \cdot 5$, pantothenic acid $5 \cdot 5$, pyridoxine $1 \cdot 1$, biotin $0 \cdot 56$, choline 1100 , cyanocobalamin 0.017, Fe 88, Zn 55, Mn 22, Cu 6.6, I 0.22, Se 0.1.

Table 2. Basal non-esterified fatty acid (NEFA), glucose and insulin concentrations and metabolic responses to insulin or fenoterol in pigs given dietary ractopamine $(R A C)^{*}$

\begin{tabular}{|c|c|c|c|c|c|c|c|c|c|c|}
\hline \multirow[b]{3}{*}{ Ractopamine. $\mathrm{HCl}(\mathrm{mg} / \mathrm{kg}) \ldots$} & \multicolumn{6}{|c|}{ Day of dietary treatment } & \multirow[b]{3}{*}{ SED $\dagger$} & \multirow{2}{*}{\multicolumn{3}{|c|}{ Significance }} \\
\hline & \multicolumn{2}{|c|}{$3 \% 4$} & \multicolumn{2}{|c|}{$9 / 10$} & \multicolumn{2}{|c|}{$23 / 24$} & & & & \\
\hline & $\mathbf{0}$ & 20 & $\mathbf{0}$ & 20 & 0 & 20 & & $\begin{array}{l}\text { RAC } \\
\text { (df 6) }\end{array}$ & $\begin{array}{c}\text { DAY } \\
\text { (df 12) }\end{array}$ & $\begin{array}{c}\mathrm{RAC} \times \mathrm{DAY} \\
(\text { (df 12) }\end{array}$ \\
\hline $\begin{array}{l}\text { Basal plasma concentrations§ } \\
\text { NEFA }(\mu \mathrm{mol} / 1) \\
\text { Glucose }(\mathrm{mmol} / 1) \\
\text { Insulin }(\mathrm{mU} / \mathrm{l})\end{array}$ & $\begin{array}{l}43 \cdot 5 \\
5 \cdot 12 \\
41 \cdot 4\end{array}$ & $\begin{array}{l}47 \cdot 5 \\
5 \cdot 16 \\
28 \cdot 0\end{array}$ & $\begin{array}{c}44 \cdot 7 \\
4 \cdot 92 \\
34 \cdot 0\end{array}$ & $\begin{array}{c}33 \cdot 9 \\
4 \cdot 86 \\
25 \cdot 3\end{array}$ & $\begin{array}{l}43 \cdot 7 \\
4 \cdot 61 \\
31 \cdot 5\end{array}$ & $\begin{array}{c}37 \cdot 4 \\
4 \cdot 56 \\
25 \cdot 8\end{array}$ & $\begin{array}{l}5 \cdot 5 \\
0 \cdot 24 \\
4 \cdot 1\end{array}$ & $\begin{array}{l}\text { NS } \\
\text { NS } \\
0.002\end{array}$ & $\begin{array}{l}\text { NS } \\
<0 \cdot 001 \\
\text { NS }\end{array}$ & $\begin{array}{l}0.062 \\
\text { NS } \\
\text { NS }\end{array}$ \\
\hline $\begin{array}{l}\text { Response to insulin } \| \\
\text { NEFA }(\mu \mathrm{mol} \mathrm{min} / 1) \\
\text { Glucose }(\mathrm{mmol} \mathrm{min} / 1)\end{array}$ & $\begin{array}{r}-114 \\
-81\end{array}$ & $\begin{array}{l}-304 \\
-102\end{array}$ & $\begin{array}{l}-22 \\
-73\end{array}$ & $\begin{array}{r}-120 \\
-67\end{array}$ & $\begin{array}{l}-86 \\
-64\end{array}$ & $\begin{array}{l}-74 \\
-85\end{array}$ & $\begin{array}{r}101 \\
9\end{array}$ & $\begin{array}{l}0.075 \\
\text { NS }\end{array}$ & $\begin{array}{l}\text { NS } \\
0.025\end{array}$ & $\begin{array}{l}\text { NS } \\
\text { NS }\end{array}$ \\
\hline $\begin{array}{l}\text { Response to fenoterol } 9 \\
\text { NEFA ( } \mu \mathrm{mol} \min / \mathrm{l}) \\
\text { Glucose }(\mathrm{mmol} \mathrm{min} / \mathrm{l}) \\
\text { Insulin }(\mathrm{mU} \mathrm{min} / \mathrm{l})\end{array}$ & $\begin{array}{r}2314 \\
11 \\
340\end{array}$ & $\begin{array}{r}1071 \\
14 \\
219\end{array}$ & $\begin{array}{r}2206 \\
29 \\
621\end{array}$ & $\begin{array}{r}554 \\
13 \\
252\end{array}$ & $\begin{array}{r}2538 \\
23 \\
567\end{array}$ & $\begin{array}{r}855 \\
22 \\
232\end{array}$ & $\begin{array}{r}194 \\
7 \\
183\end{array}$ & $\begin{array}{l}<0.001 \\
\text { NS } \\
0.023\end{array}$ & $\begin{array}{l}\text { NS } \\
\text { NS } \\
\text { NS }\end{array}$ & $\begin{array}{l}\text { NS } \\
\text { NS } \\
\text { NS }\end{array}$ \\
\hline
\end{tabular}

* Pigs were fed on diets containing either 0 or $20 \mathrm{mg}$ ractopamine $\mathrm{HCl} / \mathrm{kg}$ for $24 \mathrm{~d}$. For further details see p. 810 .

$\uparrow$ Standard error of the difference for treatment means.

NS, $P>0-10$.

$\S$ Values are the means of samples taken at $-30,-20,-10$ and $-1 \mathrm{~min}$ before insulin and fenoterol injections (plasma NEFA and glucose) or before fenoterol injection (plasma insulin).

$\|$ Area under the curve (corrected for basal) after intravenous injection of insulin $(1 \mu \mathrm{g} / \mathrm{kg}$ body weight) on days 3,9 and 23 of dietary ractopamine treatment.

TI Area under the curve (corrected for basal) after intravenous injection of fenoterol ( $2 \mu \mathrm{g} / \mathrm{kg}$ body weight) on days 4,10 and 24 of dietary ractopamine treatment.

\section{Calculations and statistics}

Responses to homeostatic signals were expressed as area under the metabolite or hormone $v$. time curve for the next $1 \mathrm{~h}$ or until circulating metabolite or hormone concentration returned to basal, whichever came first. Basal concentrations were determined as the 
Table 3. Basal non-esterified fatty acid (NEFA), glucose and insulin concentrations and metabolic responses to insulin or fenoterol in pigs previously given ractopamine*

\begin{tabular}{|c|c|c|c|c|}
\hline & \multicolumn{2}{|c|}{ Ractopamine. $\mathrm{HCl}(\mathrm{mg} / \mathrm{kg})$} & \multirow[b]{2}{*}{ SED $\dagger$} & \multirow{2}{*}{$\begin{array}{l}\text { Significance } \\
(\text { df } 6)\end{array}$} \\
\hline & 0 & 20 & & \\
\hline \multicolumn{5}{|c|}{ Basal plasma concentrations } \\
\hline NEFA $(\mu \mathrm{mol} / \mathrm{l})$ & $35 \cdot 2$ & $35-3$ & $4 \cdot 7$ & NS \\
\hline Glucose $(\mathrm{mmol} / \mathrm{l})$ & $4 \cdot 61$ & $4 \cdot 41$ & $0 \cdot 11$ & NS \\
\hline Insulin $(\mathrm{mU} / \mathrm{l})$ & 28.8 & $21 \cdot 2$ & 3.78 & NS \\
\hline \multicolumn{5}{|l|}{ Response to insulin } \\
\hline NEFA $(\mu \mathrm{mol} \mathrm{min} / \mathrm{l})$ & -12 & -52 & 60 & NS \\
\hline Glucose $(\mathrm{mmol} \mathrm{min} / 1)$ & -71 & -91 & $7 \cdot 7$ & NS \\
\hline \multicolumn{5}{|l|}{ Response to fenoterol } \\
\hline NEFA ( $\mu \mathrm{mol} \mathrm{min} / \mathrm{l})$ & 2464 & 2333 & 712 & NS \\
\hline Glucose $(\mathrm{mmol} \mathrm{min} / 1)$ & 22 & 18 & 60 & NS \\
\hline Insulin (mU min/l) & 322 & 185 & 139 & NS \\
\hline
\end{tabular}

* Pigs were fed on diets containing either 0 or $20 \mathrm{mg}$ ractopamine. $\mathrm{HCl} / \mathrm{kg}$ for $24 \mathrm{~d}$. Insulin and fenoterol challenges were conducted 6 and $7 \mathrm{~d}$ after withdrawal of ractopamine respectively. For further details, see p. 810 .

+ Standard error of the difference for treatment means.

NS, $P>0 \cdot 10$.

$\S$ Data are the means of samples taken at $-30,-20,-10$ and -1 min before insulin and fenoterol injections (plasma NEFA and glucose) or before fenoterol injection (plasma insulin).

\| Area under the curve (corrected for basal) after intravenous injection of insulin ( $1 \mu \mathrm{g} / \mathrm{kg}$ body weight) on day 6 after withdrawal of dietary ractopamine treatment.

T Area under the curve (corrected for basal) after intravenous injection of fenoterol ( $2 \mu \mathrm{g} / \mathrm{kg}$ body weight) on day 7 after withdrawal of dietary ractopamine treatment.

average of the samples taken at $-30,-20,-10$ and -1 min relative to the challenge. Statistical analyses were performed on basal concentrations averaged for days 3 and 4 (d 3/4), days 9 and 10 (d 9/10), days 23 and 24 (d 23/24) and days 30 and 31 (withdrawal). Data from the treatment period were analysed using an analysis of variance suitable for a split-plot design with treatment as the main plot and time as the subplot. Error terms used for $F$ statistics were pig within RAC for evaluating significance of RAC treatment and (pig within $\mathrm{RAC}$ ) $\times$ day for evaluating day effects and interactions. Data from the withdrawal period were compared using Student's $t$ test.

\section{RESULTS}

\section{Animal performance}

The performance of these pigs has been reported elsewhere (Dunshea \& King, 1994). Briefly, average daily gain between days 1 and 24 was increased by RAC (754 (SE 30) v. 1030 (SE 41) g/d for control $v$. RAC treatment). For the week following withdrawal of RAC there was no difference in average daily gain (674 (SE 43) v. 736 (SE 38) g/d).

\section{Basal metabolite and hormone concentrations}

Basal plasma NEFA concentrations were not significantly affected by dietary RAC or time (Table 2). While plasma glucose was not affected by dietary RAC, it did decrease with time (Table 2). Basal plasma insulin was significantly reduced by dietary RAC. During the withdrawal period there were no significant differences in basal plasma NEFA, glucose or insulin between the control animals and those that had previously received RAC (Table 3). 


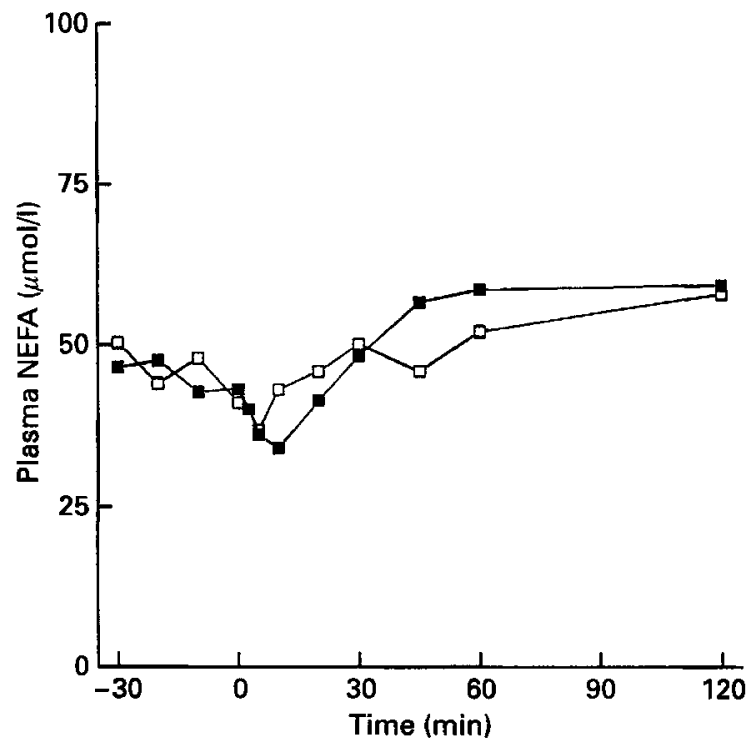

Fig. 1. Plasma non-esterified fatty acid (NEFA) response after intravenous challenge with insulin $(1 \mu \mathrm{g} / \mathrm{kg}$ body weight $)$ in gilts given $0(\square, n 4)$ or $20(\square, n 4) \mathrm{mg}$ ractopamine/ $\mathrm{kg}$ diet. Values are means for challenges conducted on days 3,9 and 23 of treatment.

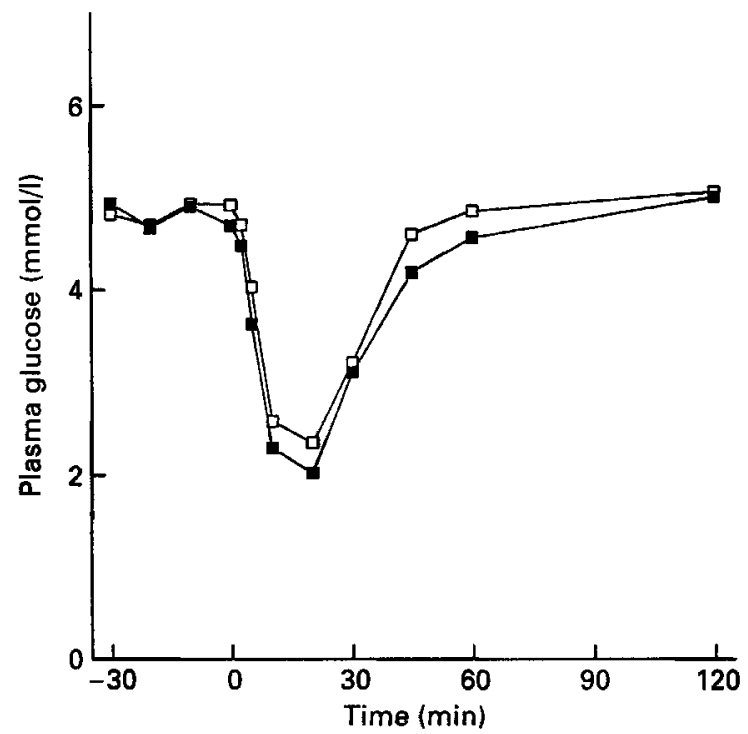

Fig. 2. Plasma glucose response after intravenous challenge with insulin ( $1 \mu \mathrm{g} / \mathrm{kg}$ body weight) in gilts given 0 $(\square, n 4)$ or $20(\square, n 4) \mathrm{mg}$ ractopamine/ $\mathrm{kg}$ diet. Values are means for challenges conducted on days 3,9 and 23 of treatment.

\section{Responses to insulin}

Insulin was anti-lipolytic as evidenced by a small decrease in plasma NEFA after insulin challenge (Fig. 1), with the plasma NEFA response tending to be greater $(P=0.075)$ in RAC-treated gilts (Table 2). The decrease in plasma NEFA after insulin injection during the withdrawal period was not different between treatment groups (Table 3). Insulin 


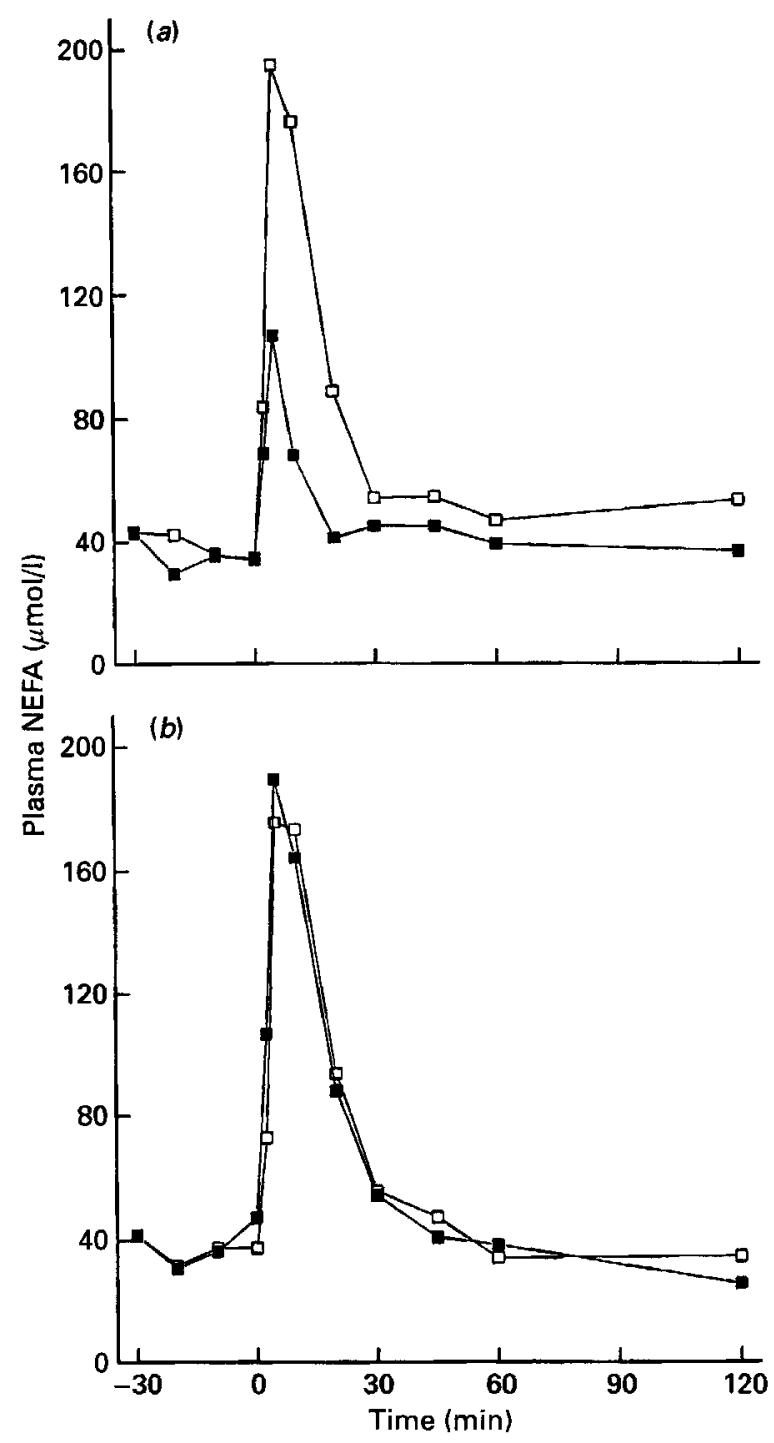

Fig. 3. Plasma non-esterified fatty acid (NEFA) response after intravenous challenge with fenoterol $(2 \mu \mathrm{g} / \mathrm{kg}$ body weight) in gilts given $0(\square, n 4)$ or $20(\square, n 4) \mathrm{mg}$ ractopamine/ $\mathrm{kg}$ diet. Values are means for challenges conducted (a) on days 4, 10 and 24 of treatment or (b) after $7 \mathrm{~d}$ of withdrawal of RAC.

injection caused acute hypoglycaemia in all pigs although there was no difference between treatments (Fig. 2, Table 2). The hypoglycaemic response to insulin decreased with time, possibly because basal blood glucose concentrations also decreased. Prior RAC treatment had no effect on the hypoglycaemic effects of insulin during the withdrawal period (Table 3).

\section{Responses to fenoterol}

Intravenous challenge with fenoterol stimulated lipolysis as evidenced by an acute increase in plasma NEFA (Fig. 3). However, the lipolytic response was markedly reduced in RACtreated gilts (Fig. 3(a), Table 2). Lipolytic responses returned to control values by $7 \mathrm{~d}$ after 


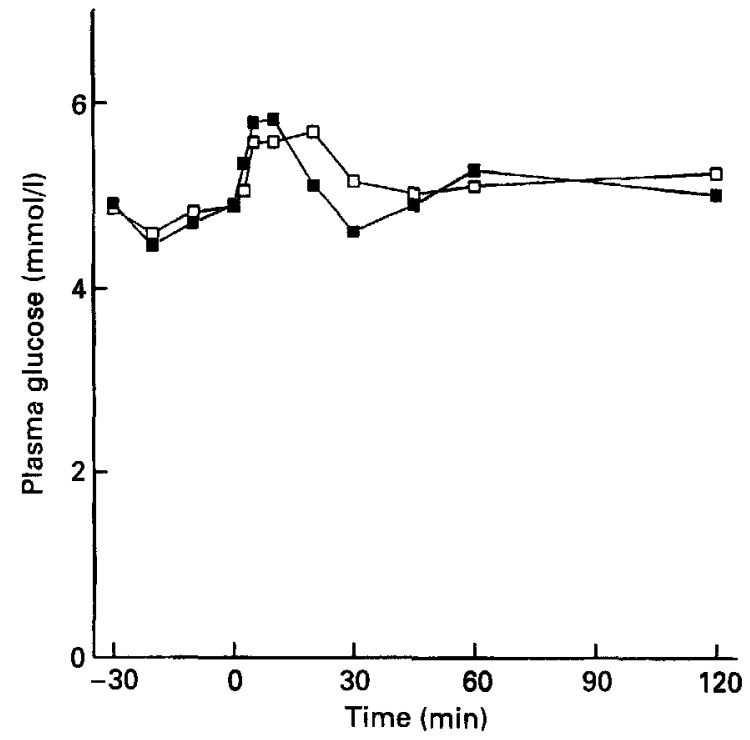

Fig. 4. Plasma glucose response after intravenous challenge with fenoterol ( $2 \mu \mathrm{g} / \mathrm{kg}$ body weight) in gilts given 0 $(\square, n 4)$ or $20(\square, n 4) \mathrm{mg}$ ractopamine/kg diet. Values are means for challenges conducted on days 4,10 and 24 of treatment.

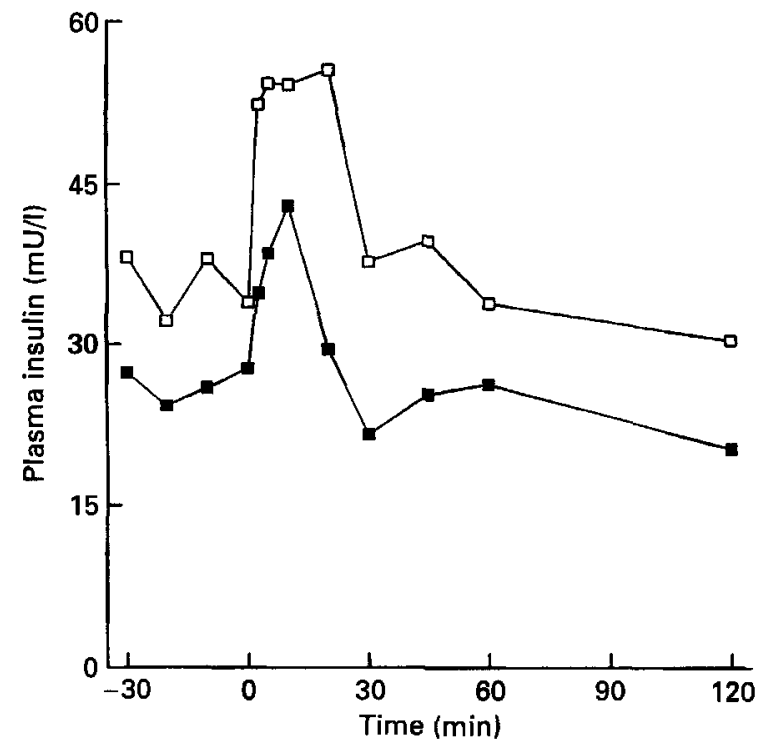

Fig. 5. Plasma insulin response after intravenous challenge with fenoterol ( $2 \mu \mathrm{g} / \mathrm{kg}$ body weight) in gilts given 0 $(\square, n 4)$ or $20(\square, n 4) \mathrm{mg}$ ractopamine/ $\mathrm{kg}$ diet. Values are means for challenges conducted on days 4,10 and 24 of treatment.

withdrawal of RAC (Figure 3(b), Table 3). Intravenous fenoterol caused mild hyperglycaemia but there was no difference between treatment groups either during dietary RAC treatment (Fig. 4, Table 2) or during the withdrawal period (Table 3). Plasma insulin also increased after fenoterol injection with this response being diminished during dietary 
RAC treatment (Fig. 5, Table 2). The fenoterol-induced hyperinsulinaemia during the withdrawal period was not affected by prior RAC treatment.

\section{DISCUSSION}

\section{Lipid metabolism}

There was no significant effect of RAC on basal plasma NEFA concentrations suggesting that RAC did not stimulate lipid mobilization or lipolysis, or if it had, that these effects had disappeared by day 3 . Interestingly, there was the suggestion of an interaction between day and RAC $(P<0.062)$, such that basal plasma NEFA decreased with time on treatment. This may occur if there is de-sensitization of adipose-tissue adrenergic response to both endogenous and exogenous stimulation. This certainly appeared to be the case with the dramatic decrease in the lipolytic response to the $\beta_{2}$-agonist fenoterol. Thus, after only $4 \mathrm{~d}$ dietary RAC treatment, while basal NEFA concentrations were not different, the lipolytic response to fenoterol was reduced to only $44 \%$ of that of the control gilts. On days 9 and 24 the NEFA responses to fenoterol challenge were only 25 and $34 \%$ that of the control pigs respectively. Response returned to control values $7 \mathrm{~d}$ after withdrawal. These results suggest that RAC treatment leads to de-sensitization of adipose-tissue $\beta$-adrenergic receptors. This apparent de-sensitization is evident as early as $4 \mathrm{~d}$ after RAC treatment and is maintained for at least 3 weeks. Withdrawal of RAC results in an equally rapid return to normal adrenergic lipolytic response.

In support of our findings in vivo, Spurlock et al. (1993) recently reported that feeding RAC for $24 \mathrm{~d}$ reduced adipose-tissue adrenergic receptor density by $50 \%$ (as assessed with isoproterenol) with differences being detectable as early as $1 \mathrm{~d}$ after feeding RAC. In contrast, Adeola et al. (1992) reported that the NEFA response to the $\left(\beta_{1}+\beta_{2}\right)$-agonist isoproterenol $(1 \mu \mathrm{g} / \mathrm{kg} \mathrm{BW})$ was greater in $\mathrm{RAC}$-treated pigs receiving a diet containing $170 \mathrm{~g} \mathrm{CP} / \mathrm{kg}$ but unchanged when the basal diet contained $130 \mathrm{~g} \mathrm{CP} / \mathrm{kg}$. However, while basal in vitro lipolysis was not affected by dietary $\mathrm{RAC}$, isoproterenol-stimulated lipolysis was reduced (Adeola et al. 1992). The reason for the different responses to the fenoterol and isoproterenol challenges is unknown but may be that the challenges were conducted on different parts of the dose-response curve. Porcine adipose tissue is more sensitive to isoproterenol than fenoterol by at least an order of magnitude whereas maximum responsiveness is not different (Mersmann, 1987). Therefore, RAC may be decreasing adipose tissue sensitivity (seen with fenoterol) but not maximum responsiveness (observed with isoproterenol) to $\beta$-adrenergic stimulation. In this context, decreased $\beta$-adrenergic sensitivity with unchanged responsiveness was evident in acute co-incubations of porcine adipocytes with RAC or clenbuterol and epinephrine (Liu \& Mills, 1989). Dietary clenbuterol also decreased in vitro adipose-tissue $\beta$-adrenergic sensitivity without changing responsiveness (Mills \& Orcutt, 1989). It should also be borne in mind that the basal plasma NEFA concentrations in the study of Adeola et al. (1992) were at least ten times higher than in the present study and are indicative of fasted and/or stressed pigs. Therefore, it is possible that their pigs had not received feed (including dietary RAC) for some time. Given the rapidity with which de-sensitization of adipose $\beta$-adrenergic receptors occurs (Spurlock et al. 1993), it is possible that the study by Adeola et al. (1992) was conducted after resensitization had occurred.

Insulin was anti-lipolytic although the magnitude of the response was relatively small (Fig. 1). In part this was due to the already low basal plasma NEFA concentrations and presumably lipolysis in these pigs. However, the response in the RAC-treated pigs tended to be greater $(P=0.075)$ than in the control pigs. If this is a real effect of RAC then it would ensure that RAC-stimulated lipolysis is kept in check by the augmented anti-lipolytic effect 
of insulin. In this context, basal plasma insulin was decreased by dietary RAC which could in turn be a response to the increased anti-lipolytic effect of insulin.

\section{Glucose metabolism}

Despite the lower circulating levels of insulin and possible augmented anti-lipolytic effect of insulin, basal blood glucose concentrations and the hypoglycaemic effect of insulin were unchanged by dietary RAC. Therefore, RAC appears to have little effect on the ability of insulin to stimulate glucose uptake by peripheral tissues in vivo. However, $\beta$-agonists such as RAC, cimaterol and isoproterenol antagonize the acute lipogenic and anti-lipolytic effects of insulin in porcine adipose tissue (Liu et al. 1989; Peterla \& Scanes, 1990) possibly through reduced binding to adipocyte insulin receptors. Incubation of porcine adipocytes with RAC and clenbuterol decreased insulin binding at low (physiological) but not high media insulin concentrations (Liu \& Mills, 1990). Whether this phenomenon occurs in vivo is still unclear. For example, while co-incubation of mouse adipocytes with RAC and clenbuterol also reduced insulin binding, adipocytes from mice treated with these $\beta$ agonists in vivo actually had higher insulin binding than adipocytes from control mice (Dubrovin et al. 1990). Therefore, there appear to be some disparate effects of RAC on acute in vitro compared with chronic in vivo actions of insulin. However, it should be noted that the chronic in vivo effects were consistent with our observations that dietary RAC has little effect on the rate of lipid deposition (Dunshea et al. 1993a,b,c).

Fenoterol-induced hyperglycaemia was not affected by dietary RAC, consistent with what is observed when RAC-treated pigs are challenged with isoproterenol (Adeola $e t$ al. 1992). Hyperglycaemia after adrenergic stimulation is generally attributed to hepatic glycogenolysis and so these results suggest that there is little change in the ability of the pig liver to respond to adrenergic stimulation during RAC treatment. However, in challengetype studies there are always counter-regulatory mechanisms operating. For example, after adrenergic stimulation there is also a period of hyperinsulinaemia, presumably in response to increased plasma glucose and NEFA. The hyperinsulinaemic response to fenoterol was reduced during RAC treatment, possibly due to the decreased NEFA response, and this may also reduce the hyperglycaemic response to fenoterol.

\section{Conclusions}

In conclusion, these results support the hypothesis that the lack of effect of dietary RAC on the rate of lipid deposition in the pig is due to a rapid de-sensitization of adipose-tissue $\beta$-adrenergic receptors. Withdrawal of RAC results in an equally rapid return to normal adrenergic lipolytic response. Dietary RAC also appears to have little effect on glucose metabolism although basal insulin concentrations are decreased.

This work was supported in part by a grant from the Australian Pig Research and Development Corporation. The authors wish to thank R. Nason and R. Biden for expert technical assistance. These results were presented in part at the 17th annual meeting of the Australian Nutrition Society (Dunshea et al. 1992).

\section{REFERENCES}

Adeola, O., McBride, B. W. \& Young, L. G. (1992). Metabolic responses induced by isoproterenol in ractopamine-fed pigs. Journal of Nutrition 122, 1280-1287.

Coutinho, L., Bergen, W., Merkel, R. \& Smith, C. (1990). Quantitative characterization of the beta-adrenergic receptor subtype in porcine adipocytes. FASEB Journal 4, 650 (Abstr.).

Dubrovin, L. C., Liu, C. Y. \& Mills, S. E. (1990). Insulin binding to mouse adipocytes exposed to clenbuterol and ractopamine in vitro and in vivo. Domestic Animal Endocrinology 7, 103-109. 
Dunshea, F. R., Eason, P. J., King, R. H. \& Campbell, R. G. (1993a). Effects of ractopamine, dietary energy and sex on protein and fat deposition in growing swine. Journal of Animal Science 71 Suppl. 1, 133 (Abstr.).

Dunshea, F. R. \& King, R. H. (1994). Temporal response of plasma metabolites to ractopamine treatment in the growing pig. Australian Journal of Agricultural Research 45, 1683-1692.

Dunshea, F. R., King, R. H., Biden, R. S. \& Nason, R. G. (1992). Responses to homeostatic signals in ractopamine-treated pigs. Proceedings of the Nutrition Society of Australia 17, 223.

Dunshea, F. R., King, R. H. \& Campbell, R. G. (1993b). Interrelationships between dietary protein and ractopamine on protein and lipid deposition in finishing gilts. Journal of Animal Science 71, 2931-2941.

Dunshea, F. R., King, R. H., Campbell, R. G., Sainz, R. D. \& Kim, Y. S. (1993c). Interrelationships between sex and ractopamine on protein and lipid deposition in rapidly growing pigs. Journal of Animal Science 71, 2919-2930.

Liu, C. Y., Boyer, J. L. \& Mills, S. E. (1989). Acute effects of beta-adrenergic agonists on porcine adipocyte metabolism in vitro. Journal of Animal Science 67, 2930-2936.

Liu, C. Y. \& Mills, S. E. (1989). Determination of the affinity of ractopamine and clenbuterol for the betaadrenoreceptor of the porcine adipocyte. Journal of Animal Science 67, 2937-2942.

Liu, C. Y. \& Mills, S. E. (1990). Decreased insulin binding to porcine adipocytes by beta-adrenergic agonists. Journal of Animal Science 68, 1603-1608.

Mersmann, H. J. (1987). Acute metabolic effects of adrenergic agents in swine. American Journal of Physiology 252, E85-E95.

Mills, S. E. \& Orcutt, A. L. (1989). Clenbuterol-induced desensitisation in murine adipocytes: relationship to in vivo effectiveness. Domestic Animal Endocrinology 6, 51-58.

Mitchell, A. D., Solomon, M. B. \& Steele, N. C. (1990). Response of low and high protein select lines of pigs to the feeding of the beta-adrenergic agonist ractopamine (phenethanolamine). Journal of Animal Science 68, 3226-3232.

Mitchell, A. D., Solomon, M. B. \& Steele, N. C. (1991). Influence of level of dietary protein or energy on effects of ractopamine in finishing swine. Journal of Animal Science 69, 4487-4495.

Peterla, T. A. \& Scanes, C. G. (1990). Effects of $\beta$-adrenergic agonists on lipolysis and lipogenesis by porcine adipose tissue in vitro. Journal of Animal Science 68, 1024-1029.

Spurlock, M. E., Cusumano, J. C., Ji, S. Q., Anderson, D. B., Hancock, D. L. \& Mills, S. E. (1993). The effect of ractopamine on $\beta$-adrenoreceptor density and affinity in porcine adipose and skeletal muscle tissue. Journal of Animal Science 71, Suppl. 1, 135 (Abstr.).

Takken, A. \& Williams, K. C. (1981). A simplified procedure for long-term catheterisation of the anterior vena cava in adult pigs. Australian Veterinary Journal 57, 17-20. 